\title{
Nutritional quality of some non-alcoholic beverages from the Romanian market
}

\author{
Buşuricu Florica ${ }^{1}$, Schroder Verginica ${ }^{1}$, Margaritti Doina ${ }^{1}$, Anghel Andreea \\ Hortensa $^{2}$, Tomoș Sirma ${ }^{1}$ \\ ${ }^{1}$ Faculty of Pharmacy, "Ovidius" University of Constanta, Romania \\ ${ }^{2}$ Faculty of Biology, "Ovidius" University of Constanta, Romania \\ Email: florica.busuricu@365.univ-ovidius.ro
}

\begin{abstract}
In the recent years, young consumers choose to consume from the category of soft drinks, without acknowledging that their health may be endangered. To this end, we aim to contribute to the real scientific estimation of the nutrient intake from a number of 20 waters with vitamins and minerals having a reduced addition of fruit extract (1-3\%), compared to juices that have 10-30 \% fruits extract, from those sold in Romania. We analyzed the presentation of the nutritional declaration, the quality of the additives and the profiling of nutrients through the SENS system. The obtained results classify the products in the category of those with low energy value and in the category "significant sources of vitamins and minerals"; there are from food classes 2 and 4, as a nutritional profile
\end{abstract}

Keywords. nutritional quality, SENS system, non-alcoholic beverages

\section{Introduction}

Health conscious people are increasingly interested in vitamins and minerals.

Few of the vitamins needed by the human body are biosynthesized (through vitaminogenesis, the intestinal flora produces vitamin $\mathrm{K}$, pantothenic acid and folic acid often in insufficient quantities to the body), so that the daily requirement is provided by food and supplemented by food supplements or functional foods. Poor dietary intake of vitamins and minerals leads to the installation of specific clinical syndromes, as a result of absorption disorders or some excessive loss through various metabolic pathways [1].

The importance of vitamins, minerals and polyphenols for the body determined the producers to produce new non-alcoholic drinks, so that in the last 5 years we witness an abundance of water with vitamins and minerals $(\mathrm{Mg}, \mathrm{Zn}, \mathrm{Ca}) \pm$ fruit extracts; energy drinks; assortments of tea infusions and lemonades with extract and aroma (pomegranate, blueberry, apple, aloe vera, lemon, grapefruit, red oranges). The producers of these drinks want, over time, to distinguish these non-alcoholic drinks, in the segment of beverages with beneficial functionality, a category already appreciated on the international market. Active consumers, with a healthy lifestyle, correlated with certain activities, such as practicing sports and exercise, practicing activities that support the well-being of the body, choose to buy water with vitamins and minerals with low added fruits (1-3\%), focusing more on the functional advantages of ready-to-drink products, to the detriment of the option for fresh fruit [2].

Fruits consumed as such, compared to the juices obtained from them, add value - dietary fiber. Consumed daily, dietary fiber ensures intestinal transit and helps maintain a healthy weight. Studies also confirm that fiber: reduces the absorption of cholesterol and glucose from food, thus preventing cardiovascular disease and diabetes; detoxifies the body of toxic, preand carcinogenic secondary metabolites; reduces the bioavailability of hazardous metal 
compounds in food, such as mercury accumulated in fish [3]. The presence of fiber in fruits, along with vitamins and minerals, could motivate the choice of consuming a whole fruit, instead of the drink obtained from the fruit.

Recent studies on vitaminizing waters, marketed in the country and abroad, show for many of them, an unsatisfactory nutritional profile for health. They are products sweetened with sugar, contain additives, vitamins and synthetic minerals and with an insignificant intake of polyphenols [4, 5]. An essential factor in ensuring the quality of these soft drinks is the natural source used by the water. Climate change and artificial pollution often alter the chemical composition of groundwater, which can make the drinking process difficult, which increases the risk of endangering the health of consumers [6].

In this paper, we aim to perform an analysis of the nutritional quality of a number of 20 soft drinks sold in Romania, in terms of: expression and presentation of the nutritional statement, quality of additives and nutrient profiling through the SENS system. The aim of this paper is to contribute to the real scientific estimation of the nutrient intake from the marketed products and to make the consumer aware that not all the marketed products are beneficial to health.

\section{Materials and methods}

2.1. The analyzed samples are of 5 categories, coming from different producers (Table 1), as follows:

- category I - 5 waters with added vitamins and synthetic minerals, with fruit aroma (fruit concentrate $2-3.5 \%$ );

- category II - 3 water products with vitamins and $\mathrm{Mg} / \mathrm{Zn}$;

- category III- 2 water products with $\mathrm{Zn} / \mathrm{Mg}$;

- category IV - 6 juice products with fruit extract 10-12\%, coming from 2 different producers;

- category V- 4 juice products with fruit extract 25-30\%, coming from 2 different producers.

\subsection{Evaluation of nutritional labeling and quality of additives}

The nutrition declaration was analyzed in accordance with the legislation in force $[7,8]$ following: energy value, energy nutrient factors, coverage expressed as a percentage of RDA per $100 \mathrm{~mL}$ of product, additives used.

\subsection{Nutrient profiling through the SENS system, derived from the SAIN - LIM system}

In order to calculate the SAIN score, the recommended daily values for the nutrients with positive impact (proteins, fibers, folic acid, vitamin $\mathrm{C}$ and calcium) are taken into account, respectively, for the LIM score, the negative ones (sugars, fats, salt).

The values of the SAIN and LIM indicators for the analyzed samples were compared with the acceptability thresholds 5 , respectively 7.5 , being possible their classification in one of the 4 classes defined by authors of this SENS system [7, 8]. Fig. 1 shows the classification of the products in the 4 classes $[9,10]$. 


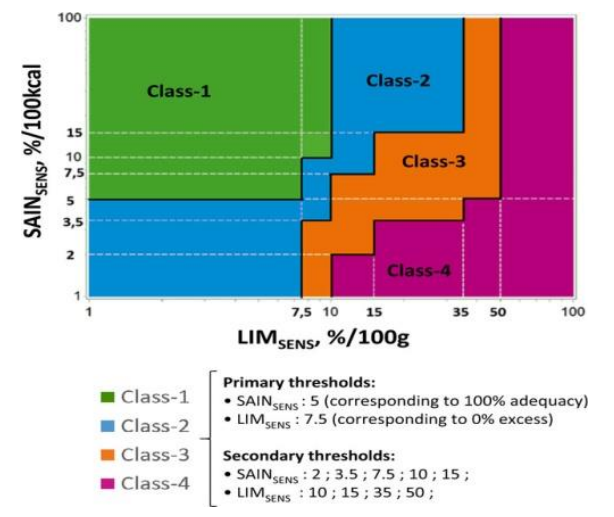

Fig 1 - Classification of products according to the SENS system

The calculation formulas for the 2 scores are [11]:

$$
\begin{aligned}
\text { SAIN } & =\frac{\sum_{p=1}^{5} N u t p / M R V p}{5} \times 100 \\
\text { LIM } & =\frac{\sum_{p=1}^{3} \frac{\text { Li p }}{\text { MRV p }}}{3} \times 100
\end{aligned}
$$

Nut $\mathrm{p}=$ the amount (in $\mathrm{g}, \mathrm{mg}$ or $\mu \mathrm{g}$ ) of nutrient $\mathrm{p}$ (positive) in the food that provides $100 \mathrm{Kcal}$ (in accordance with Regulation EU No 1169, 2011)

MRV $\mathrm{p}=$ the maximum amount of nutrient allowed (in accordance with Regulation EU No 1169, 2011)

$\mathrm{Li}=$ nutrient limit $\mathrm{p}$ (negative) in food (in accordance with Regulation EU No 1169, 2011 and WHO)

\section{Results and discussion}

\subsection{Evaluation of the nutrition declaration and the quality of the additives}

By analyzing the product label, it was found that the nutritional information on the energy value and chemical composition of the nutrients - Table 1, according to the legislation in force $[7,8]$.

Thus, the products of category I, II and III are with low energy value and low sugar content (contain $3.2 \mathrm{~g}$ sugars / $100 \mathrm{~mL}$, equivalent to 12.8-19.2 g sugars / serving and have $14-18 \mathrm{Kcal} / 100 \mathrm{~mL}$ ). The products from category IV and V have a higher energy value (42$48 \mathrm{kcal} / 100 \mathrm{~mL}$ ), respectively a high sugar content, compared to the previous ones (sugars 10$11 \mathrm{~g} / 100 \mathrm{~mL}$ and $25-27.5 \mathrm{~g} /$ portion). If we take into account the portion of product recommended by the manufacturer and the permissible limit of WHO sugars (at a requirement of $2000 \mathrm{Kcal} /$ day, the sugars must cover $10 \%$ and be $50 \mathrm{~g} /$ day), both contribute with a sufficiently high intake. Thus, the first 3 categories of products bring from one portion an intake between $25 \%-38.4 \%$, and the other categories, an intake of 50-55\%, which increases the danger of high blood sugar.

The nature of the ingredients is presented, specifying the role of each additive. Natural dyes are used - carotenes, saffron and anthocyanins from added fruit extracts, chosen from 
those that have polyphenols, such as: currants, pomegranates, acai, pineapple, coconut, apples, lemon. We also note that all products are preserved by pasteurization, except for those in category II, which use benzoate and sorbate for preservation, which will diminish their quality, given the toxic potential of these preservatives $[12,13]$.

The results obtained prove the sale of products that are not so safe for health, especially as they are sweetened with sugar, have additives and consumed more than one serving, they can endanger health. Recent studies prove the same phenomenon of commercial promotion of nutritionally unbalanced foods, in all categories, on a global scale [14, 15].

Table 1- The analyzed products and the results obtained from the analysis of the nutritional profile

\begin{tabular}{|c|c|c|c|c|}
\hline The analyzed sample & $\begin{array}{l}\text { Caloric } \\
\text { value } \\
\text { kcal/100mL } \\
*\end{array}$ & $\begin{array}{l}\text { SAIN } \\
\text { Score }\end{array}$ & $\begin{array}{l}\text { LIM } \\
\text { Score }\end{array}$ & Food class \\
\hline \multicolumn{5}{|l|}{ Category I } \\
\hline VW1.Vitamin aqua+Mg (carbonate) & 14 & 0 & 5.5 & (Class 2) \\
\hline VW2. Vitamin aqua $+Z n$ (gluconate) & 18 & 0 & 5.6 & (Class 2) \\
\hline VW3. Vitamin aqua + D+ Ca (lactate) & 14 & 0 & 5.5 & (Class 2) \\
\hline VW4. Vitamin aqua $+\mathrm{B}$ & 14 & 0 & 5.6 & (Class 2) \\
\hline VW5. Vitamin aqua $+\mathrm{C}$ & 18 & 14.44 & 7.17 & (Class 1) \\
\hline \multicolumn{5}{|l|}{ II. Category } \\
\hline TW1.+ Mg (citrate) & 13 & 0 & 5.17 & (Class 2) \\
\hline TW2. + Zn (gluconate) & 13 & 0 & 5.23 & (Class 2) \\
\hline TW3. +vitamins B & 13 & 0 & 5.23 & (Class 2) \\
\hline \multicolumn{5}{|l|}{ III. Category } \\
\hline AW1. $+\mathrm{Mg}$ (chloride) & 14 & 0 & 5.6 & (Class 2) \\
\hline AW2. + Zn (gluconate) & 14 & 0 & 7.75 & (Class 3) \\
\hline IV. Juice with fruit extract $10-12 \%$ & 42 & & & \\
\hline PF1 (cherries 9\% +1\%grapes) & 48 & 0 & 21.20 & (Class 4) \\
\hline PF2 (10\% pearches) & 48 & 0 & 19.375 & (Class 4) \\
\hline PF3 (12\% orange) & 46 & 0 & 18.875 & (Class 4) \\
\hline P J1 (8\% cherries) & 45 & 0 & 17,70 & (Class 4) \\
\hline PJ2 (8\% apples) & 45 & 0 & 17.70 & (Class 4) \\
\hline PJ3 (10\% orange) & 46 & 0 & 18.875 & (Class 4) \\
\hline \multicolumn{5}{|l|}{ V. Juice with aloe vera extract } \\
\hline VS1 $30 \%$ aloe vera & 44 & 0 & 20.41 & (Class 4) \\
\hline VS2 (30\% aloe vera $+0.1 \%$ pomegranate) & 39 & 0 & 16.73 & (Class 4) \\
\hline VJ1 $20 \%$ aloe vera & 45 & 0 & 17.70 & (Class 4) \\
\hline VJ2 (20\% aloe vera $+0.5 \%$ vitamin C) & 46 & 5.43 & 18.875 & (Class 2) \\
\hline
\end{tabular}

* the portions are: $600 \mathrm{~mL}$ for category I and II; 400mL for category III; $250 \mathrm{~mL}$ for category IV and $V$ 


\subsection{Nutrient profiling through the SENS system, derived from the SAIN-LIM system}

For the analyzed samples, the values of the SAIN indicator are zero, except for the sample that has vitamin C (SAIN = 14.44), and the LIN indicator varied between 5.23-17.66 which includes most samples I, II and III in food class 2, and the categories IV and V, are from food class 4 (Table 1).

Class 2 corresponds to neutral foods for health, which can be consumed in combination with foods of Class 1; and for Class 4 (SAIN less than 5 and LIM greater than 7.5) correspond foods whose consumption should be limited or better avoided, being with a partially balanced profile.

The soft drinks analyzed with fruit extract in proportions of 10-30\% (category IV and V), compared to the others, will provide the consumer with a significant intake of vitamins and minerals, but also polyphenols. Although they fall into class 4 (they do not provide us with nutrients with a positive impact), they can occasionally be considered natural sources of polyphenols. There are many studies that highlight the health benefits of polyphenols in plant products. Having antioxidant properties, they prevent coronary heart disease, inflammation, diabetes, cancer and aging [16].

In the following research we aim to determine the total polyphenol content, correlated with the antioxidant activity of the present analyzed products.

\section{Conclusions}

Although they are produced in the category of those with low energy value and in the category of "significant sources of vitamins and minerals", the products in this study are mostly foods with an unbalanced nutritional profile from the food classes 2 and 4 . Except for those that have 10-30\% fruit extract, in which the polyphenol content satisfies the minimum need for polyphenols / day, water samples do not contain these nutrients.

Therefore, we draw consumers' attention to a careful evaluation of labels and the consumption of these products, occasionally or not at all. The globalization of the modern food industry has as a consequence the creation of new products, diminishing the quality in favor of the quantity, with the possibility of endangering health.

\section{References}

[1] E. IONICĂ, M. COSTACHE: Biochimie Generală: Vitamine şi Elemente Minerale (Vol III). ISBN: 978-973-558-767-7 (Editura Ars Docendi). Universitatea din Bucureşti, România, 2013.

[2] M. VLASCHI: Se formează o nouă categorie: Apele cu vitamine şi minerale. Revista Piaţa Ediţie digitală (2020).

[3] N. ABDULLAH: Mercury in the diet, absorption and bio accessibili; Technium BioChemMed Vol. 1, Issue 1: pp.18-30 (2020).

[4] M.S.IGLESIAS, M. L. S.VAESKEN, G.V. MOREIRAS: Composition and Nutrient Information of Non-Alcoholic Beverages in the Spanish Market: Nutrients.; 8(10): 618, 2-12, doi: 10.3390/nu8100618 (2016).

[5] S. R. G. PATIÑO, L. TOLENTINO-MAYO, E.A.F. MONTERRUBIO, J.L HARRIS, S. VANDEVIJVERE, A. J. RIVERA, S. BARQUERA: Nutritional quality of foods and non-alcoholic beverages advertised on Mexican television 
according to three nutrient profile models, BMC Public Health. ; volume 16,733: 211(2016).

[6] F. SHARIFI, M. SALIH: Determining the Physical and Chemical Characteristics of Groundwater in $4^{\text {th }}$ District of Kabul City, Afghanistan: A cross-sectional study; Technium BioChemMed, Vol. 2, Issue 2: 86-98 (2021)

[7] ***REGULATION (EU) No 1169/2011 of the European Parliament and of the Council of 25 October 2011 on the Provision of Food Information to Consumers

[8] ***REGULATION (EU) No 1924/2006 of the European Parliament and of the Council of 20 December 2006 on Nutrition and Health Claims Made on Foods; OJ L 404 : 9-25

[9] N. DARMON, J. SONDEY, V. BRAESCO, M. MAILLOT: The SENS algorithm-A new nutrient profiling system for food labelling in Europe: Eur J Clin Nutr. 72 (2): 236-248: DOI: 10.1038/s41430-017-0017-6 (2018).

[10] M. MAILlOT, J. SONDEY, S. BRAESCO, N. DARMON: The Simplified Nutrient Profiling System (SENS) adequately classifies foods according to the overall nutritional quality of diets: a validation study, Journal of Clinical Nutrition, Vol 72, pp 593-602 (2018)

[11] M. GRIGORAŞ: The impact of food package information in guding consumer choices: Journal „ECONOMICA” nr.1 (99). 19-36: CZU: 338.439.5:659.154 (2017).

[12] J. PEREZ-JIMENEZ,V. NEVEU, F.VOS, A.SCALBERT: Identification of the 100 richest dietary sources of polyphenols: an application of the Phenol-Explorer database, European Journal of Clinical Nutrition. Vol 64: 112-120 (2010).

[13] F. BUŞURICU, V. SCHRODER, D. MARGARITTI, D. NADOLU, A.H.ANGHEL: Preliminary study regarding sodium benzoate and other food dyes sinergic action using BSLA citotoxicity test; Scientific Papers. Series D. Animal Science. Vol. LXII, No. 1, 410416 (2019).

[14] S.R.GALLARDO Patiño, L.TOLENTINO-MAYO, E.A.F. MONTERRUBIO, .J. L HARRIS, S. VANDEVIJVERE, J. A RIVERA, S. BARQUERA: Nutritional quality of foods and non-alcoholic beverages advertised on Mexican television according to three nutrient profile models, BMC Public Health. volume 16:733: 2-11(2016).

[15] C.O. BOGDAN, L.VOINEA, A.FILIP, R.DINA: Cercetarea discrepanţei dintre atractivitatea produselor alimentare şi profilul nutriţional real - condiţie esenţială pentru consolidarea educaţiei nutriţionale şi protecţia drepturilor consumatorilor, Protecţia drepturilor consumatorilor într-o eră a schimbărilor tehnologice şi a globalizării, Amfiteatru economic; Vol. XVI, Nr. 36: 383-3962014 (2014).

[16] F. BUŞURICU, A. ANGHEL, D. MARGARITTI, S. TOMOŞ, V. SCHRODER: The influence of thermal processing on antioxidant capacity of tomatoes based products; ARS Medica Tomitana, 3(25): 114 - 119; doi: 10.2478/arsm-2019-0023(2019) 